University of Nebraska - Lincoln

DigitalCommons@University of Nebraska - Lincoln

\title{
Forage Quality, Mineral Constituents, and Performance of Beef Yearlings Grazing Two Crested Wheatgrasses
}

\author{
Kenneth P. Vogel \\ University of Nebraska-Lincoln, kvogel1@unl.edu \\ B. C. Gabrielsen \\ J.M. Lord, Inc. \\ Bruce E. Anderson \\ University of Nebraska-Lincoln, banderson1@unl.edu \\ J. K. Ward \\ University of Nebraska-Lincoln \\ H. F. Mayland \\ USDA-ARS
}

See next page for additional authors

Follow this and additional works at: https://digitalcommons.unl.edu/usdaarsfacpub

\footnotetext{
Vogel, Kenneth P.; Gabrielsen, B. C.; Anderson, Bruce E.; Ward, J. K.; Mayland, H. F.; and Masters, R. A., "Forage Quality, Mineral Constituents, and Performance of Beef Yearlings Grazing Two Crested Wheatgrasses" (1993). Publications from USDA-ARS / UNL Faculty. 1903.

https://digitalcommons.unl.edu/usdaarsfacpub/1903
}

This Article is brought to you for free and open access by the U.S. Department of Agriculture: Agricultural Research Service, Lincoln, Nebraska at DigitalCommons@University of Nebraska - Lincoln. It has been accepted for inclusion in Publications from USDA-ARS / UNL Faculty by an authorized administrator of DigitalCommons@University of Nebraska - Lincoln. 


\section{Authors}

Kenneth P. Vogel, B. C. Gabrielsen, Bruce E. Anderson, J. K. Ward, H. F. Mayland, and R. A. Masters 


\title{
Forage Quality, Mineral Constituents, and Performance of Beef Yearlings Grazing Two Crested Wheatgrasses
}

\author{
K. P. Vogel, * B. C. Gabrielsen, J. K. Ward, B. E. Anderson, H. F. Mayland, and R. A. Masters
}

\begin{abstract}
In the central Great Plains, crested wheatgrasses [Ag:ropyron cristatum (L.) Gaetner and $A$, desertorium (Fischer ex Link) Schultes] are best utilized for early spring and late fall grazing. The principal objective of this study was to determine if beef (Bos taurus L.) yearlings grazing 'Ruff' $(A$. cristatum) during the spring grazing season had higher average daily gains and gains per hectare than cattle grazing 'Nordan' (A. desertorum). These cultivars were evaluated in grazing trials (four replications) in eastern Nebraska in 1985, 1986, and 1987. The 0.8-ha pastures were seeded in the fall of 1983 on a Typic Argiudoll soil and were fertilized annually with 68 to $90 \mathrm{~kg} \mathrm{~N} \mathrm{lia-1.} \mathrm{Grazing}$ was for 6 wk each spring by yearling steers with a begiuning average weight of $250 \mathrm{~kg}$. Averaged over $3 \mathrm{yr}$, Ruff produced higher gains per hectare than Nordan ( 272 vs $245 \mathrm{~kg} \mathrm{ha}^{-1}$ ) probably because it produced more herbage because of its better persistence. At the end of the trial, the averge basal cover of Ruff and Nordan were 21 and $6 \%$, respectively. Three-year mean average daily gains were Ruff $=$ 1.28 vs. Nordan $=1.34 \mathrm{~kg} \mathrm{~d}^{-1}$, which were unexpected, because Ruff generally had higher forage quality as measured by an array of parameters. Ruff forage had a higher, less desirable grass tetany ratio $[\mathrm{K} / \mathrm{Mg}+\mathrm{Ca})]$ than Nordan (2.6 vs. 2.3) averaged over 3 yr. Cattle grazing Ruff had lower blood serum Mg levels than sattle grazing Nordan (15.4 vs. $16.2 \mathrm{mg} \mathrm{L}^{-1}$, both of which were below the hypomagnesemia threshold of $18 \mathrm{mg} \mathrm{L}^{-1}$. This condition may have reduced intake and animal gains. These results indicate the need for evaluating pasture and range grass cultivars under grazing conditions.
\end{abstract}

$\mathrm{C}$ RESTED WHEATGRASSES are important perennial cool-season forage grasses in western North America (Rogler and Lorenz, 1983). In the central Great Plains where the native rangeland is comprised primarily of warm-season grasses, crested wheatgrass is best utilized as a short-season grass for early spring and late fall grazing. Crested wheatgrass can be grazed about $6 \mathrm{wk}$ prior to the time when the native rangeland is available for grazing. Spring forage of crested wheatgrass can meet the critical need of beef cows (Bos taurus L.) with calves and yearlings for high quality forage. Crested wheatgrass declines in forage quality as it matures in late spring and early summer and in the central Great Plains its productivity during the summer is limited (Newell and Moline, 1978).

Nordan, a tetraploid $A$. desertorum wheatgrass, and Ruff, a diploid $A$. cristatum wheatgrass, are recommended for use in this region. Nordan, which was developed by USDA-ARS at Mandan, ND, is the most widely grown crested wheatgrass in North America. Ruff was developed by USDA-ARS and the University of Nebraska and released in 1974. Both cultivars

K.P. Vogel, USDA-ARS and Dep. of Agronomy, Univ. of Nebraska; B.C. Gabrielsen, J.M. Lord, Inc., 267 N. Fulton Ave., Fresno, CA 93701; B.E. Anderson, Dep. of Agronomy, Univ. of Nebraska; J.K. Ward, Dep. of Animal Science, Univ. of $\mathrm{Ne}$ braska; H.F. Mayland, USDA-ARS, Kimberly, II) 83341; and R.A. Masters, USDA-ARS and Dep. of Agronotny, Univ. of Nebraska, Lincoln, NE 68583. Paper no. 9583 of the Journal Series of the Nebraska Agric. Res. Div. in cooperation with the USDA-ARS. Received 17 May 1991. * Corresponding author.

Published in Agron. J. 85:584-590 (1993). were released because of desirable agronomic traits. However, neither was evaluated for forage quality or animal performance prior to release. In recent small plot trials (Lamb et al., 1984; Vogel et al., 1987), Ruff was consistently higher in in vitro dry matter digestibility (IVDMD) than Nordan by approximately $15 \mathrm{~g} \mathrm{~kg}^{-1}$. In the small plot trials, herbage yields of both cultivars were similiar. Small improvements in IVDMD of the same magnitude have significantly improved average daily gains of beef cattle grazing bermudagrass [(Cynodon dactylon (L.) Pers. var. dactylon)] (Chapman et al., 1972) and switchgrass (Panicum virgatum L.) (Anderson et al., 1988).

The principal objective of this study was to determine if beef yearlings grazing Ruff during early spring had higher average daily gains and gains per hectare than cattle grazing Nordan. Because of the unexpected results obtained during the first grazing season, the study was expanded to include mineral analyses of the herbage and animal blood serum as well as determinations of persistence.

Previous grazing studies with crested wheatgrasses have generally evaluated grazing management practices or compared animal gains to those observed on other forage grasses. This grazing research has been summarized by Mayland (1986). Grazing studies comparing different cultivars of crested wheatgrass have not been reported previously except for palatability trials (Gomm, 1969; Murray, 1984). Limited differences were observed among crested wheatgrasses for visual estimates of palatability in these trials.

Crested wheatgrass forage does not appear to contain significant amounts of toxic compounds except occasionally high levels of nitrates and trans-aconitic acid have been reported (Mayland, 1986). The latter may reduce magnesium availability to livestock, resulting in hypomagnesemia, or grass tetany (Mayland and Grunes, 1979). Ruminant livestock grazing crested wheatgrass in the spring can be affected by grass tetany, resulting in production losses (Mayland, 1986). Recently, Vogel et al. (1989) and Mayland and Asay (1989) reported significant genetic differences among crested wheatgrass strains for grass tetany potential as measured by forage $\mathrm{Mg}, \mathrm{Ca}$, and $\mathrm{K}$ concentrations expressed as a ratio $[\mathrm{K} /(\mathrm{Ca}+\mathrm{Mg})]$. The grass tetany potential for Ruff was higher than that of Nordan (Vogel et al., 1989). In addition to causing grass tetany, low levels of $\mathrm{Mg}$ in the diet can lead to inappetence and reduced dry matter intake by livestock (Mosely and Griffiths, 1984; Littledike and Goff, 1987; Scott et al., 1980).

\section{MATERIALS AND METHODS}

The study was conducted over three grazing seasons from 1985 through 1987 at the University of Nebraska Agricultural Research and Development Center near Mead, NE, which is located $35 \mathrm{~km}$ west of Omaha, NE. Ruff and Nordan crested

Abbreviations: IVDMD, in vitro dry matter digestibility; ADF, acid detergent fiber; NDF, neutral detergent fiber, FA, ferulic acid; $P C A, p$-coumaric acid; and ADG, average daily gain. 
wheatgrass were planted in 0.8-ha pastures during September 1983. Eight pastures were established in a randomized complete block design with four replicate pastures per cultivar. The soil was a Sharpsburg silty clay loam (fine, montmorillonitic, mesic, Typic Argiudoll). In 1984, the pastures were harvested for hay after the grasses headed.

Prior to each grazing season, pastures were burned in early spring about $30 \mathrm{~d}$ before grazing to remove residue from the previous year and to control weeds, primarily annual Bromus species. Pastures were fertilized with $\mathrm{N}\left(\mathrm{NH}_{4} \mathrm{NO}_{3}\right)$ as follows: 18 Oct. 1984, $67 \mathrm{~kg} \mathrm{~N}^{-1}$; 6 Aug. $1985,90 \mathrm{~kg} \mathrm{~N} \mathrm{ha}^{-1} ; 28$ Aug. 1986, $84 \mathrm{~kg} \mathrm{~N} \mathrm{ha}^{-1}$; and 16 April 1987, $84 \mathrm{~kg} \mathrm{~N} \mathrm{ha}^{-1}$. Broadleaf weeds were controlled by early spring or fall applications of 2,4-D [(2,4-dichlorophenoxy) acetic acid] at rates of 1.1 or $2.2 \mathrm{~kg} \mathrm{ha}^{-1}$. Alachor (2-chloro-2',6'-diethyl-N(methoxymethyl)-acetanilide) was applied in late summer of 1984 and 1985 at a rate of $2.2 \mathrm{~kg} \mathrm{ha}^{-1}$ to control annual Bromus spp.

Pastures were grazed continuously by cross-bred Angus $x$ Hereford $\times$ Simmental yearling steers in the spring of 1985 , 1986, and 1987. Experimental animals represented the middle weight group of a larger number of steers wintered to gain approximately $0.5 \mathrm{~kg}$ animal-1 $\mathrm{d}^{-1}$. Yearlings had ad libitum access to water and salt. Initial steer weights at the beginning of the grazing season averaged 260,220 , and $280 \mathrm{~kg}$ per animal, respectively, in 1985, 1986, and 1987. Steers were weighed following an overnight shrink at the beginning and end of the grazing trial each year.

Four steers were allocated randomly to each 0.8 -ha pasture at the beginning of each grazing season. On 13 May 1986, two steers were removed from two Nordan pastures because those pastures had only $43 \%$ of the herbage mass of Ruff pastures in those replicates. Likewise, on 6 May 1987, two steers were removed from three Nordan pastures and one steer was removed from the other Nordan pasture due to lower herbage mass than the corresponding Ruff pasture. Stocking density was adjusted to keep herbage allowance similiar between cultivars. Initial stocking density was set to allow little herbage mass to remain following the brief spring grazing season and was based on previous small plot research at Mead (Vogel et al., 1987) in which crested wheatgrass produced about $4.5 \mathrm{Mg}$ $\mathrm{ha}^{-1}$ herbage during the spring growing season.

Forage sampling periods were initiated and terminated each year to coincide with the first and last day of grazing, respectively. Herbage mass was determined weekly by harvesting all forage above a $2.5-\mathrm{cm}$ cutting height in three randomly placed 30 -by $182-\mathrm{cm}$ frames in each pasture. Previously harvested areas were not reharvested using the sampling frames. Forage samples for quality analyses were taken on the same days as the herbage mass samples from (i) the portion of the plants the animals were grazing which was visually assessed as the top $1 / 3$ of the plants (grazed herbage), (ii) all herbage above 2.5 cm (total herbage), and (iii) from four caged enclosures (1.2 by 1.5 by $1.5 \mathrm{~m}$ ) per pasture (ungrazed herbage). Only previously unclipped plants within an enclosure were sampled for the ungrazed herbage samples. The grazed and total herbage quality samples for a specific date and pasture were obtained by collecting approximately six sub-samples at random in a pasture and compositing samples by sample type. Ungrazed samples were obtained by sampling herbage above $2.5 \mathrm{~cm}$ in each of the four cages in a pasture. Samples were dried in a forced-draft oven at $55^{\circ} \mathrm{C}$ to constant weight, ground to pass a $1-\mathrm{mm}$ screen in a Thomas Wiley ${ }^{1}$ mill with stainless steel blades, and stored in plastic vials at room temperature until analyzed.

Estimates of forage digestibility (IVDMD) used the twostage method of Tilley and Terry (1963) with minor modifi-

\footnotetext{
${ }^{1}$ Names of products are included for the benefit of the reader and do not imply endorsement by the USDA or the Univ. of Nebraska.
}

cations $\left(\mathrm{HgCl}_{2}\right.$ and $\mathrm{Na}_{2} \mathrm{CO}_{3}$ were not added after the first step). The rumen fluid was a mixture taken from two fistulated steers maintained on separate diets of alfalfa (Medicago sativa L.)smooth bromegrass (Bromus inermis Leyss.) hay or ground corn (Zea mays L.) cobs. Crude protein concentration $(\mathrm{N} \times$ 6.25) was determined following the Kjeldahl procedure (A.O.A.C., 1975). Neutral-detergent fiber (NDF), acid-detergent fiber (ADF), and lignin (permanganate-oxidation) concentrations were sequentially determined as described by Van Soest and Robertson (1980). Alkali-labile phenolics, ferulic acid (FA), and $p$-courmaric acid (PA) were extracted and analyzed from air-dried NDF residues with high performance liquid chromatography (HPLC) methods (Gabrielsen et al., 1990).

Forage samples were analyzed for $\mathrm{Ca}, \mathrm{Mg}$, and $\mathrm{K}$ concentration each year. In 1986, the forage material was also analyzed for $\mathrm{S}, \mathrm{P}, \mathrm{Zn}, \mathrm{Mn}, \mathrm{Cu}$, and $\mathrm{Fe}$ concentration to screen for possible differences in these elements between the two cultivars. Blood was collected from all yearlings in the study by jugular puncture on three dates in 1986 and five dates in 1987. The collection dates generally coincided with the beginning, middle, and end of the grazing season each year. Elemental analyses for both forage and blood serum samples were conducted using procedures described by Vogel et al. (1989). In brief, both forage and blood serum samples were digested in a 3:1 nitric-perchloric acid solution and diluted with a $1 \mathrm{~g}$ $\mathrm{L}^{-1} \mathrm{La}\left(\right.$ as $\mathrm{LaCl}_{2}$ ) solution. Magnesium and $\mathrm{Ca}$ were analyzed by atomic absorption and $\mathbf{K}$ by flame emission. Analytical accuracy was typified by a 99,98 , and $98 \%$ mean recovery of $\mathrm{Ca}, \mathrm{Mg}$, and $\mathrm{K}$, respectively, using citrus leaf samples from the National Institute of Standards and Technology (SRM-1572). Phosphorus was determined colorimetrically as molybdovanado-phosphoric acid and other elements were determined by atomic absorption. The grass tetany ratio, $\mathrm{K} /(\mathrm{Ca}+\mathrm{Mg})$, was calculated on an equivalents per kilogram basis.

Prior to the initiation of the grazing trial, soil samples were taken from each pasture. Soil from $0-$ to $30-\mathrm{cm}$ and $30-$ to $60-$ $\mathrm{cm}$ depths was collected and composited separately for each pasture. Soil samples were analyzed by the University of $\mathrm{Ne}$ braska Soil Testing Lab for the routinely determined soil characteristics.

At the end of the grazing trial in 1987 , basal cover of each cultivar was determined by using an inclined 10-point frame. The frame was placed at $6-\mathrm{m}$ intervals along four $60-\mathrm{m}$ transects located in each pasture (40 frames/pasture). Each point intercept was recorded as either bare ground, mulch (dead plant residue), or crested wheatgrass.

The experimental design was a randomized complete block with four replicates. Analyses of variance (ANOVA) procedures were used to determine if mean differences between cultivars were significant for the traits evaluated (Steel and Torrie, 1960). Since in 1986 and 1987 some yearlings were periodically removed from the Nordan pastures to maintain a similar herbage allowance between cultivars, average daily gains were determined using data from animals that remained in the test pastures for the duration of a grazing season. Gains per hectare were calculated as mean average daily gain by grazing days for each pasture.

\section{RESULTS AND DISCUSSION Stands}

Annual precipitation for 1985,1986 , and 1987 was 665,965 , and $772 \mathrm{~mm}$, respectively so moisture was not a limiting factor. Precipitation distribution among and within years was variable, as is typical in the Great Plains (Fig. 1). Excellent uniform stands were present on all pastures at the beginning of the study, so no initial stand data were collected. Excellent stands persisted throughout the 1985 grazing season. By the spring of 1986, 


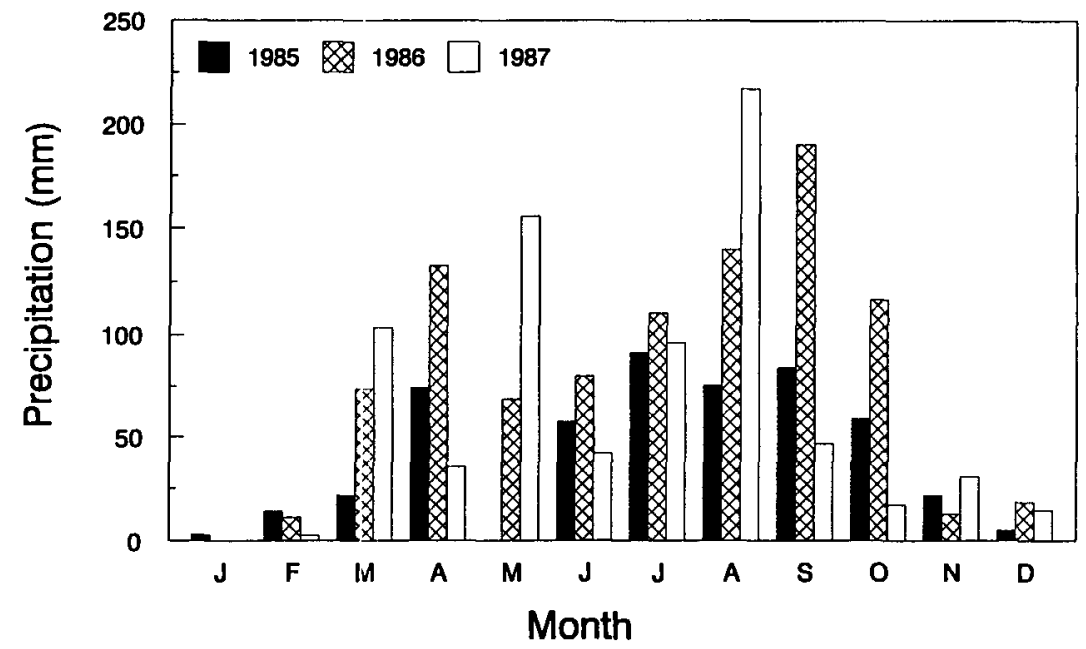

Fig. 1. Precipitation at Mead, NE, in 1985, 1986, and 1987.

stands in the Nordan pastures were diminishing and the plants in the Nordan pastures were not as robust as the previous year. By the fall of 1987, the basal cover of Ruff was $21 \pm 1 \%$ versus $6 \pm 2 \%$ for Nordan. Because of the loss of stand in the Nordan pastures, stocking density was reduced on Nordan pastures in 1986 and 1987. The loss of stands in the Nordan pastures was due to crown-rot diseases possibly caused by Helminthosporium or Fusarium spp., which were previously implicated in stand losses of crested wheatgrass in this region (Lamb et al., 1984). Ruff was not affected and maintained excellent stands throughout the study.

\section{Herbage Mass and Allowance}

Herbage mass of Ruff and Nordan did not differ in 1985 and 1986 when averaged over weekly samples and pastures (Table 1). In 1985, there were no differences between the cultivars for herbage mass on any sampling date (individual sampling date data not shoven). However, Ruff pastures had more herbage mass on the first sampling date in 1986 and during the latter part of the 1986 grazing season herbage mass in two of the four Nordan pastures averaged less than one-half of the herbage mass in corresponding Ruff pastures. For this reason, stocking density in those pastures was reduced. Ruff produced significantly more herbage mass than Nordan in 1987 (averaged over sampling dates, Table 1) because of better stands. Ruff pastures had significantly more herbage mass than Nordan for the first five sampling

Table 1. Herbage mass of two crested wheatgrass cultivars during three grazing seasons at Mead, NE.

\begin{tabular}{|c|c|c|c|c|}
\hline \multirow[b]{2}{*}{ Cultivar } & \multicolumn{4}{|c|}{ Herbage mass $\dagger$} \\
\hline & $\overline{1985}$ & 1986 & 1987 & 3-yr mean \\
\hline & & & $a^{-1}$ & \\
\hline $\begin{array}{l}\text { Ruff } \\
\text { Nordan } \\
\text { SE }\end{array}$ & $\begin{array}{r}1790 \\
1860 \\
186\end{array}$ & $\begin{array}{l}814 \\
674 \\
109\end{array}$ & $\begin{array}{c}700^{*} \\
523 \\
92\end{array}$ & $\begin{array}{r}1101 \\
1018 \\
134\end{array}$ \\
\hline
\end{tabular}

dates but there were no differences for the last two sarnpling dates in 1987.

Stocking density was reduced on Nordan pastures in 1986 and 1987 after $14 \mathrm{~d}$ of grazing to equalize herbage allowance between cultivars. Average herbage allowance for Ruff vs Nordan expressed as kilograms per animal was 362 vs. 377 in 1985, 165 vs. 165 in 1986, and 142 vs. 151 in 1987. Although herbage allowance differed among years, the average herbage allowance was very similar between the cultivars within years due to the reductions in stocking density that were made in the Nordan pastures.

\section{Forage Quality}

Data from the total herbage samples are not presented because the results were consistent with data from grazed herbage and ungrazed herbage samples. In 1985 when pastures of both cultivars were in good condition, ADF and lignin concentrations were significantly lower and IVDMD was higher in grazed herbage of Ruff (Table 2). Superior forage quality of Ruff was also indicated by lower PCA concentration and higher FA/PCA ratios in the forage cell walls (NDF is considered to be cell wall material). In addition, PCA concentration in the forage cell walls increased at a slower rate in Ruff throughout each grazing season and was highly correlated $(r>-0.95, P \leq 0.001)$ with changes in IVDMD of both cultivars (data not shown). In a grazing trial of three switchgrass strains, lower levels of PCA and higher FA/ PCA ratios in the forage cell wall were strongly associated with forage digestibility and animal performance (Gabrielsen et al. 1990). No differences between the cultivars for CP or FA were apparent. In 1986 and 1987 NDF was slightly higher in Ruff for grazed herbage and in 1987 for ungrazed herbage (Tables 2 and 3). During 1986 and 1987 , the other forage quality parameter values were similar or if different indicated a slight superiority of Ruff compared to Nordan (Tables 2 and 3). Based on visual observations in the pastures, Ruff was perceived to have higher forage quality because of greater succulence, leafiness, and later flowering. 
Table 2. Forage quality constituents in grazed herbage of two crested wheatgrass cultivars during three grazing seasons at Mead, NE.

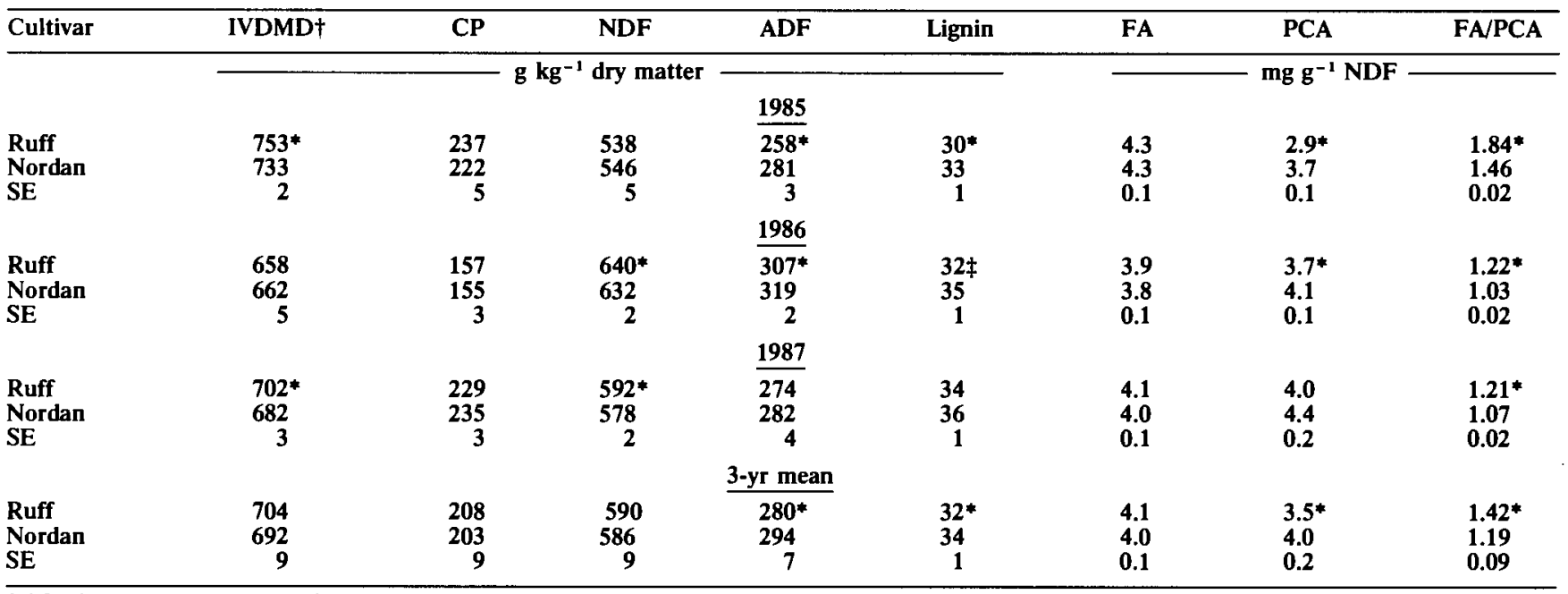

$\$, *$ Indicates means are significantly different at the 0.1 and 0.05 levels of probability, respectively.

+ IVDMD $=$ in vitro dry matter digestibility; $C P=$ crude protein; $N D F=$ neutral detergent fiber; $A D F=$ acid detergent fiber; Lignin = permanganate lignin; $\mathbf{F A}=$ ferulic acid; $\mathbf{P C A}=p$-coumaric acid.

\section{Cattle Gains}

In 1985, average daily gains (ADG) of cattle grazing Nordan were higher than those grazing Ruff (Table 4). Since stocking rates were the same, gains per hectare also were higher on Nordan than on Ruff (Table 4). These results were unexpected because herbage mass in 1985 was similar for the two cultivars (Table 1) and Ruff and higher quality forage as determined by most forage quality parameters (Tables 2 and 3 ) particularly for the grazed herbage samples.

In 1986 and 1987, ADG did not differ among cattle grazing Ruff and Nordan. Ruff produced more kilograms of beef per hectare than Nordan in 1986 and 1987 but the differences were not significant. Averaged over $3 \mathrm{yr}$, there were no differences between cultivars for ADG but Ruff produced more gain per hectare because of more herbage mass in 1986 and 1987 due to better stands that permitted higher stocking densities. The ADG obtained for the yearlings grazing both cultivars were higher than or comparable to gains obtained for cattle in previous studies evaluating crested wheatgrass (Malechek, 1986; Hart et al., 1983).

Since some research (Moseley and Griffiths, 1984; Littledike and Goff, 1987; Scott et al., 1980) indicates that $\mathrm{Mg}$ deficiencies can affect forage intake and subsequently livestock gains, the study was expanded to include analyses of forage and blood serum mineral concentrations to attempt to explain the results.

Table 3. Forage quality constituents in ungrazed herbage from caged enclosures of two crested wheatgrass cultivars during three grazing seasons at Mead, NE.

\begin{tabular}{|c|c|c|c|c|c|c|c|c|}
\hline Cultivar & IVDMD† & $\mathbf{C P}$ & NDF & ADF & Lignin & $\mathbf{F A}$ & PCA & FA/PCA \\
\hline & \multirow{2}{*}{\multicolumn{5}{|c|}{$\mathrm{g} \mathrm{kg}^{-1}$ dry matter }} & \multicolumn{3}{|c|}{$\mathrm{mg} \mathrm{g}^{-1} \mathrm{NDF}$} \\
\hline & & & & & & & & \\
\hline \multirow[t]{2}{*}{$\begin{array}{l}\text { Ruff } \\
\text { Nordan } \\
\text { SE }\end{array}$} & $\begin{array}{r}737 \\
732 \\
3\end{array}$ & $\begin{array}{r}228 \\
218 \\
6\end{array}$ & $\begin{array}{r}545 \\
544 \\
3\end{array}$ & $\begin{array}{c}\overline{266 \ddagger} \\
276 \\
3\end{array}$ & $\begin{array}{r}32 \\
33 \\
1\end{array}$ & $\begin{array}{l}4.5 \\
4.4 \\
0.1\end{array}$ & $\begin{array}{l}2.9^{*} \\
3.4 \\
0.1\end{array}$ & $\begin{array}{l}1.85^{*} \\
1.61 \\
0.04\end{array}$ \\
\hline & & & & 1986 & & & & \\
\hline $\begin{array}{l}\text { Ruff } \\
\text { Nordan } \\
\text { SE }\end{array}$ & $\begin{array}{r}668 \\
670 \\
6\end{array}$ & $\begin{array}{r}162 \\
160 \\
8\end{array}$ & $\begin{array}{r}615 \\
615 \\
5\end{array}$ & $\begin{array}{c}290^{*} \\
311 \\
2\end{array}$ & $\begin{array}{c}30^{*} \\
34 \\
1\end{array}$ & $\begin{array}{l}4.2 \\
3.9 \\
0.2\end{array}$ & $\begin{array}{l}3.3^{*} \\
3.8 \\
0.1\end{array}$ & $\begin{array}{l}1.37^{*} \\
1.15 \\
0.04\end{array}$ \\
\hline & & & & 1987 & & & & \\
\hline $\begin{array}{l}\text { Ruff } \\
\text { Nordan } \\
\text { SE }\end{array}$ & $\begin{array}{r}686 \\
687 \\
8\end{array}$ & $\begin{array}{r}216 \\
226 \\
5\end{array}$ & $\begin{array}{c}573^{*} \\
551 \\
2\end{array}$ & $\begin{array}{r}269 \\
274 \\
2\end{array}$ & $\begin{array}{r}34 \\
32 \\
2\end{array}$ & $\begin{array}{l}3.8 \\
3.7 \\
0.2\end{array}$ & $\begin{array}{l}3.4 \\
3.8 \\
0.2\end{array}$ & $\begin{array}{l}1.30 \\
1.16 \\
0.05\end{array}$ \\
\hline SE & & & & 3-yr mear & & & & \\
\hline $\begin{array}{l}\text { Ruff } \\
\text { Nordan } \\
\text { SE }\end{array}$ & $\begin{array}{r}697 \\
696 \\
8\end{array}$ & $\begin{array}{r}202 \\
201 \\
12\end{array}$ & $\begin{array}{r}577 \\
569 \\
10\end{array}$ & $\begin{array}{r}275 \\
287 \\
7\end{array}$ & $\begin{array}{r}32 \\
33 \\
2\end{array}$ & $\begin{array}{l}4.1 \\
4.0 \\
0.2\end{array}$ & $\begin{array}{l}3.2^{*} \\
3.7 \\
0.2\end{array}$ & $\begin{array}{l}1.50^{*} \\
1.30 \\
0.08\end{array}$ \\
\hline
\end{tabular}

$\ddagger, *$ Indicates means are significantly different at the 0.1 and 0.05 levels of probability, respectively.

† IVDMD = in vitro dry matter digestibility; $\mathrm{CP}=$ crude protein; $\mathrm{NDF}=$ neutral detergent fiber; $\mathrm{ADF}=$ acid detergent fiber; Lignin = permanganate lignin; FA = ferulic acid; PCA = p-coumaric acid. 
Table 4. Average daily gain (ADG) and gain per hectare of beef yearlings grazing two crested wheatgrass cultivars during 3 yr at Mead, NE.

\begin{tabular}{|c|c|c|c|c|c|c|c|c|}
\hline \multirow[b]{2}{*}{ Cultivar } & \multicolumn{2}{|c|}{$1985 \dagger$} & \multicolumn{2}{|c|}{$1986 \ddagger$} & \multicolumn{2}{|c|}{$1987 \S$} & \multicolumn{2}{|c|}{ 3-yr Mean } \\
\hline & Gain ha ${ }^{-1}$ & $\mathrm{ADG}+$ & Ciain ha-1 & ADG† & Gain ha-1 & $\overline{A D G}+$ & Gain ha & $\overline{\mathrm{ADG}} \dagger$ \\
\hline & & & & & 272 & & & \\
\hline $\begin{array}{l}\text { Ruff } \\
\text { Nordan }\end{array}$ & $\begin{array}{l}3169 \\
\mathbf{3 4 7}\end{array}$ & $\begin{array}{l}1.469 \\
1.60\end{array}$ & $\begin{array}{l}226 \\
196\end{array}$ & $\begin{array}{l}1.06 \\
1.12\end{array}$ & $\begin{array}{l}272 \\
193\end{array}$ & $\begin{array}{l}1.32 \\
1.30\end{array}$ & $\begin{array}{l}2729 \\
245\end{array}$ & $\begin{array}{l}1.28 \\
1.34\end{array}$ \\
\hline SE & 8 & 0.04 & 20 & 0.07 & 27 & 0.10 & 8 & 0.04 \\
\hline
\end{tabular}

† Four steers per 0.81-ha pasture. Grazing period 17 April to 31 May (44 d).

\# Average of 4 and 3.3 steers per 0.81 -ha pasture for Ruff and Nordan, respectively. Grazing period 30 April to 12 June (43 d).

$\$$ Average of 4 and 2.8 steers per 0.81 -ha pasture for Rıff and Nordan, respectively. Grazing duration 22 April to 3 June (42 d).

II Indicates the means were significantly different at the 0.1 level of probability.

Table 5. Forage mineral constituents in grazed and ungrazed forage of two crested wheatgrass cultivars during three grazing seasons at Mead, NE.

\begin{tabular}{|c|c|c|c|c|c|c|c|c|}
\hline \multirow[b]{2}{*}{ Cultivar } & \multicolumn{4}{|c|}{ Grazed $\dagger$} & \multicolumn{4}{|c|}{ Ungrazed $\neq$} \\
\hline & $\mathbf{M g}$ & $\mathrm{Ca}$ & $\mathbf{K}$ & $\mathrm{K} /(\mathrm{Mg}+\mathrm{Ca}) \S$ & $\mathbf{M g}$ & $\mathrm{Ca}$ & $\mathbf{K}$ & $\mathrm{K} /(\mathrm{Mg}+\mathrm{Ca})$ \\
\hline \multicolumn{9}{|c|}{$-\mathrm{mg} \mathrm{g}^{-1}$ dry matter } \\
\hline \multicolumn{9}{|c|}{1985} \\
\hline Ruff & 1.3 & 2.99 & $23.7^{*}$ & $2.4^{*}$ & 1.3 & $3.1^{*}$ & 24.3 & $2.4 \pi$ \\
\hline Nordan & 1.3 & 3.2 & 21.9 & 2.2 & 1.3 & 3.5 & 24.1 & 2.2 \\
\hline SE & 0.1 & 0.1 & 0.2 & 0.1 & 0.1 & 0.1 & 0.2 & \\
\hline \multicolumn{9}{|c|}{1986} \\
\hline Ruff & 1.2 & 2.8 & $22.6^{*}$ & $2.5^{*}$ & 1.2 & 3.2 & 22.7 & 2.2 \\
\hline Nordan & 1.2 & 3.0 & 21.5 & 2.2 & 1.2 & 3.4 & 22.3 & 2.1 \\
\hline $\mathbf{S E}$ & 0.1 & 0.1 & 0.2 & & 0.1 & 0.1 & 0.6 & 0.1 \\
\hline \multicolumn{9}{|c|}{1987} \\
\hline Ruff & 1.2 & 2.5 & $26.0^{*}$ & $3.0^{*}$ & 1.2 & $2.9 \pi$ & $28.4^{*}$ & $3.0^{*}$ \\
\hline Nordan & 1.2 & 2.8 & 23.6 & 2.5 & 1.3 & 3.5 & 27.1 & 2.5 \\
\hline SE & 0.1 & 0.1 & 0.3 & 0.1 & 0.1 & 0.2 & 0.2 & 0.1 \\
\hline \multicolumn{9}{|c|}{ 3-yr mean } \\
\hline Ruff & 1.2 & $2.8^{*}$ & $24.1^{*}$ & 2.69 & 1.3 & 3.11 & 25.1 & $2.5 \pi$ \\
\hline Nordan & 1.2 & 3.0 & 22.3 & 2.3 & 1.3 & 3.5 & 24.5 & 2.3 \\
\hline & 0.1 & 0.1 & 0.2 & 0.1 & 0.1 & 0,1 & 0.4 & 0.1 \\
\hline
\end{tabular}

I,* Indicates the means were significantly different at the 0.1 and 0.05 levels of probability, respectively.

+ Forage clipped from the upper one-third of grazed plants.

¥ Whole plant samples from caged enclosures.

$\$$ Calculated on an equivalents per kilogram basis.

\section{Minerals}

Ruminants grazing cool-season grasses are subject to grass tetany (i.e., hypomagnesemia) during the early spring and occasionally during autumn (Mayland and Grunes, 1979; Mayland, 1986). Grass tetany is a complex nutritional disorder caused by a deficiency of $\mathrm{Mg}$ in the diet or an interference with $\mathbf{K}$ or some other constituent with the efficiency of $\mathrm{Mg}$ absorption by the animal (Grunes, 1973; Grunes, et al., 1970; Littledike and Goff, 1987). Although the disorder may result in death of the grazing animal, decreases in production due to sub-acute levels of hypomagnesemia causing reduced forage intake or reduced forage digestibility have been described previously (Ammerman et al., 1971, Moseley and Griffiths, 1984; Littledike and Goff, 1987; Scott, et al., 1980). Research on $\mathrm{Mg}$ requirements for growing and finishing beef cattle is limited but a range of 0.5 to $2.5 \mathrm{~g} \mathrm{~kg}^{-1}$ with a maximum level of $4.0 \mathrm{~g} \mathrm{~kg}^{-1}$ has been established by the NAS/NRC (1984). This range is apparently based on the requirement for calves (NAS/NRC, 1984). Kincaid (1988) indicates that elemental $\mathrm{Mg}$ levels in blood serum of cattle should be greater than $18 \mathrm{mg} \mathrm{L}^{-1}$ to maintain good health. Because of the interactions of $\mathrm{Mg}$, $\mathrm{Ca}$, and $\mathrm{K}$ in hypomagnesemia, a cation ratio, $\mathrm{K} /(\mathrm{Ca}$
$+\mathrm{Mg}$ ), is used to estimate the grass tetany potential of a forage. This ratio should be 2.2 or less for a forage to be safe in terms of its potential for inducing grass tetany in lactating cows (Mayland and Grunes, 1979).

In 1985, the crested wheatgrass cultivars did not differ in $\mathrm{Mg}$ content but Ruff herbage contained significantly less $\mathrm{Ca}$ than did Nordan (Table 5). This difference was apparent in both grazed and ungrazed herbage. In addition, Ruff had significantly more $\mathrm{K}$ in grazed herbage and higher $\mathrm{K} /(\mathrm{Ca}+\mathrm{Mg})$ values in both forage treatments than did Nordan. Because of higher $\mathrm{K}$ and $\mathrm{K} /(\mathrm{Ca}$ $+\mathrm{Mg}$ ) values, $\mathrm{Mg}$ absorption by the yearlings probably was less from Ruff herbage than from Nordan. Similar results were obtained on forage collected during 1986 and 1987 (Table 5). Concentrations of other elements (i.e., P, S, Zn, Mn, and Fe) were within normal limits for ruminant requirements (data not shown).

Concentration of serum $\mathrm{Mg}$ in 1986 and 1987 was significantly lower in animals grazing Ruff, while differences for $\mathrm{Ca}$ and $\mathrm{K}$ content were not apparent (Table 6). The lower serum $\mathrm{Mg}$ levels in yearlings grazing Ruff may have resulted from a negative effect of the higher $\mathbf{K}$ in the forage when compared to Nordan (Table 5). Information on the critical level of $\mathrm{Mg}$ (i.e., serum $\mathrm{Mg}$ 
Table 6. Mineral constituents in the blood serum of yearlings grazing two crested wheatgrass cultivars during two grazing seasons at Mead, NE.

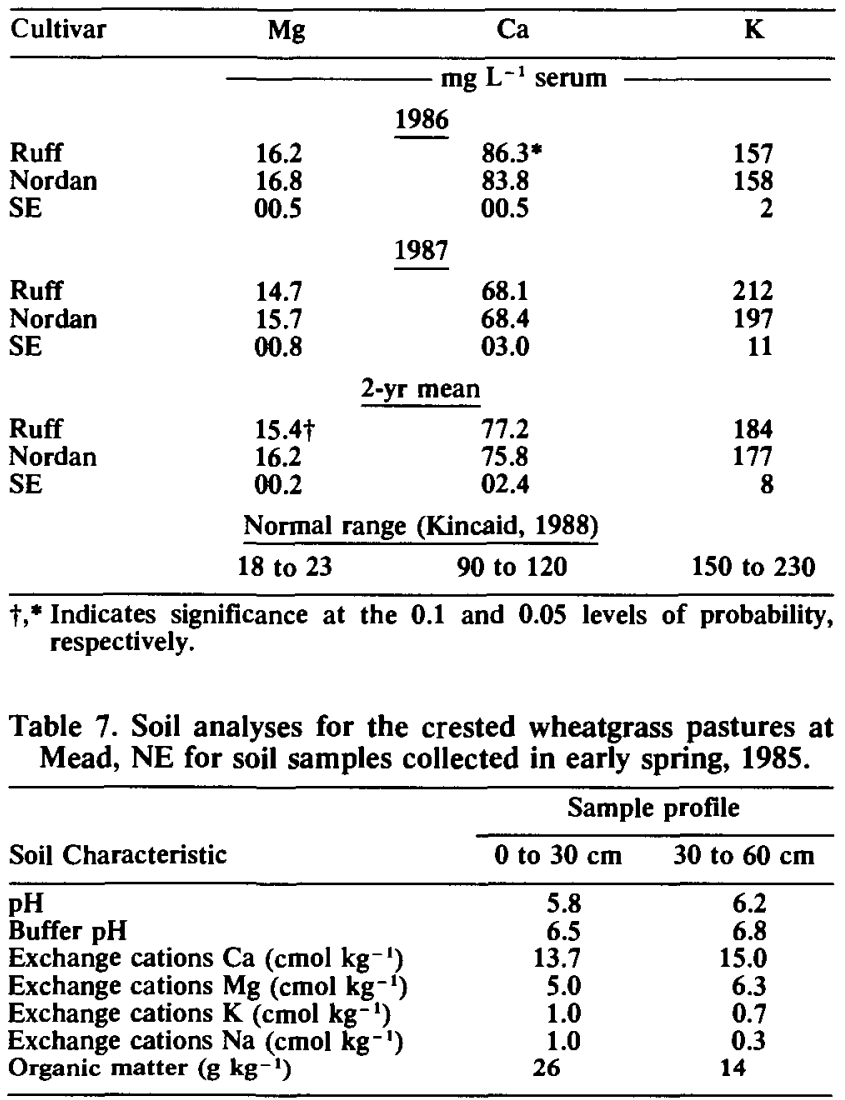

$\left.<18 \mathrm{mg} \mathrm{L}^{-1}\right)$ in beef and dairy cattle blood serum is based primarily on studies with lactating cows (Mayland, 1988; Kincaid, 1988). If this information is applicable to beef yearlings then steers on both pastures were hypomagnesemic. Possibly the lower serum $\mathrm{Mg}$ levels in yearlings grazing Ruff may have reduced dry matter intake and digestion efficiency to a greater extent than for animals grazing Nordan pastures. Since we did not collect blood samples in 1985, we have not data to support this hypothesis. Additional research will be needed to determine the effect of low levels of $\mathrm{Mg}$ on gains of beef yearlings. The high gains of steers on both pastures and absence of clinical symptoms associated with hypomagnesemia indicate that the acute level of $\mathrm{Mg}$ in blood serum for beef yearlings probably is lower than that observed in this study. The results also question the validity of extrapolating Mg requirements for calves and lactating cows to beef yearlings.

Mineral concentrations of the soil were within normal ranges for soils of the Great Plains (Table 7) and were adequate for normal plant growth. Soil mineral concentration differences among pastures were minimal (data not shown). In previous small plot research, Vogel et al. (1989) reported that Ruff had higher $\mathrm{K}$ and $\mathrm{K}(\mathrm{Ca}+$ $\mathrm{Mg}$ ) values than Nordan in herbage collected at heading. The results of this study are consistent with the previous report which indicates that samples from small plots are predictive of forage mineral content from pastures over several grazing seasons.

\section{SUMMARY}

Perennial pasture and range grasses should establish easily and persist under grazing conditions, and they need to produce high yields of animal products. In this study, excellent gains were made by beef yearlings on both cultivars. Ruff produced more beef per hectare than Nordan because of its better persistence. Because Ruff had higher IVDMD than Nordan in previous studies, it was expected that animals grazing Ruff would have higher daily gains than cattle gazing Nordan. This did not occur even though Ruff generally exhibited higher quality forage as measured by an array of forage quality parameters except for mineral composition. Results confirm that in crested wheatgrass, quality factors other than forage digestibility also may affect animal performance. The combined effects of forage digestibility and mineral content on livestock performance require additional research.

\section{REFERENCES}

Association of Official Analytical Chemists (A.O.A.C.). 1975. Methods of analysis. Washington, DC.

Anderson, B., J.K. Ward, K.P. Vogel, M.G. Ward, H.J. Gorz, and F.A. Haskins. 1988. Forage quality and performance of yearlings grazing switchgrass strains selected for differing digestibility. J. Anim. Sci. 66:2239-2244.

Ammerman, C.B., C.F. Chicco, J.E. Moore, P.A. Walleghem, and L.R. Arrington. 1971. Effect of dietary magnesium on voluntary feed intake and rumen fermentation. J. Dairy Sci. $54: 1288-1293$

Chapman, H.P., W.H. Marchant, P.R. Utley, R.E. Helwig, and W.G. Monson. 1972. Performance of steers on Pensacola bahiagrass, Coastal bermudagrass, and Coastcross-1 bermudagrass pastures and pellets. J. Anim. Sci. 34:373-378.

Gabrielsen, B.C., K.P. Vogel, B.E. Anderson, and J.K. Ward. 1990. Alkali-labile lignin phenolics and forage quality in three switchgrass strains selected for differing digestibility. Crop Sci. 30:1313-1320.

Gomm, F.B. 1969. The palatability of range and pastures grasses in Montana. Montana Agric. Exp. Stn. Bull. 619.

Grunes, D.L., R.P. Stout, and J.R. Brownell. 1970. Grass tetany of ruminants. Adv. Agron. 22:331-374.

Grunes, D.L. 1973. Grass tetany of cattle and sheep p. 113-140. In A.G. Matches (ed.) Antiquality components of forages. CSSA Spec. Publ. 4. ASA, CSSA, and SSSA, Madison, WI.

Hart, R.H., E.F. Balla, and J.W. Waggoner, Jr. 1983. Gains of steers and calves grazing crested wheatgrass. J. Range Manage. 36:483-484.

Kincaid, K. 1988. Macroelements for ruminants. p. 326-346. In D.C. Church (ed.) The ruminant animal: Digestive physiology and nutrition. Prentice Hall, Englewood Cliffs, NJ.

Lamb, J.F.S., K.P. Vogel, and P.E. Reece. 1984. Genotype and genotype $\mathbf{x}$ environment interaction effects on forage yield and quality of crested wheatgrasses. Crop Sci. 24:559-564.

Littledike, E.T., and J. Goff. 1987. Interactions of calcium, phosphorus, magnesium, and vitamin $D$ that influence their status in domestic meat animals. J. Anim. Sci. 65:1727-1743.

National Academy of Sciences/National Research Council. 1984. Nutrient requirements of beef cattle. 6th ed. National Academy of Science, Washington, DC.

Newell, L.C., and W.J. Moline. 1978. Forage evaluations of twelve grasses in relation to season for grazing. Nebr. Agr. Exp. Stn. Res. Bull. 283.

Malechek, J.C. 1986. Nutritional limits of crested wheatgrass for range livestock production. p. 267-272. In K.L. Johnson (ed.) Crested wheatgrass: Its values, problems, and myths. Symp. Proc., Logan, UT. 3-7 Oct. 1983. Utah State Univ., Logan, UT.

Mayland, H.F. 1986. Factors affecting yield and nutritional quality of crested wheatgrass. p. 215-266. In K.L. Johnson (ed.) Crested wheatgrass: Its values, problems, and myths. Symp. Proc., Logan, UT. 3-7 Oct. 1983, Utah State Univ., Logan UT.

Mayland, H.F. 1988. Grass tetany. p. 511-523 and 530-531. In D.C. Church (ed.) The ruminant animal: Its physiology and nutrition. Prentice-Hall, Englewood Cliffs, NJ.

Mayland, H.F., and K.H. Asay. 1989. Genetic variability of Mg, 
$\mathrm{Ca}$, and $\mathrm{K}$ in crested wheatgrass. J. Range Manage. 42:109113.

Mayland, H.F., and D.L. Grunes. 1979. Soil-climate-plant relationships in the etiology of grass tetany. p. 123-175. In V.V. Rendig and D.L. Grunes (ed.) Grass tetany. ASA, CSSA, and SSSA, Madison, WI.

Moseley, G., and D.W. Griffiths. 1984. The mineral metabolism of sheep fed high- and low-magnesium selections of Italian ryegrass. Grass For Sci. 39:195-199.

Murray, Robert B. 1984. Yields, nutrient quality, and palatability to sheep of fourteen grass accessions for potential use in sagebrush-grass range in southeastern Idaho. J. Range Manage. 37:343-347.

Rogler, G.A., and R.J. Lorenz. 1983. Crested wheatgrass. Early history in the United States. J. Range Management 36:91-93.

Scott, P.R., J.N. Kelley, D.A. Whitaker, and N.D. Cameron. 1980. Marginal magnesium deficiency as a possible cause of reduced voluntary feed intake in commercially managed dairy cows. Vet. Res. Comm. 4:225-229.
Steel, R.G.D., and James H. Torrie. 1960. Principles and procedures of statistics. McGraw-Hill Book Company, Inc., New York.

Tilley, J.M.A., and R.A. Terry. 1963. A two stage technique for in vitro digestion of forage crops. J. Br. Grassl. Soc. 18:104111.

Van Soest, P.J., and J.B. Robertson. 1980. Systems of analysis for evaluating fibrous feeds. p. 49-60. In W.J. Pigden, C.C Balch, and M. Graham (ed.) Standardization of analytical methodology for feeds. Internationsl Development Research Centre. IDRC-134e. Ottawa, Canada.

Vogel, K.P., H.G. Jung, and P.E. Reece. 1987. Performance and potential of intergeneric wheatgrass hybrids in the Central Great Plains. Crop Sci. 27:8-13.

Vogel, K.P., H.F. Mayland, P.E. Reece, and J.F.S. Lamb. 1989 Genetic variability for mineral element concentration of crested wheatgrass forage. Crop Sci. 29:1146-1150. 